\title{
Tendency to contact general practice instead of self-care: a population vignette study
}

\author{
Alicia O'Cathain ${ }^{1 \star}$, Rebecca Simpson ${ }^{1}$, Miranda Phillips², Jon M Dickson ${ }^{3}$ \\ ${ }^{1}$ School of Health and Related Research, University of Sheffield, Sheffield, UK; \\ ${ }^{2} \mathrm{NatCen}$ Social Research, London, UK; ${ }^{3}$ The Academic Unit of Primary Medical Care, \\ The Medical School, University of Sheffield, Sheffield, UK
}

\begin{abstract}
Background: Demand for general practice in the UK is higher than supply. Some patients seek appointments with GPs for minor illnesses rather than self-care.

Aim: To identify the characteristics of people with a tendency to contact GPs rather than self-care.

Design \& setting: A national survey of the British adult population was undertaken in 2018, which included vignettes.

Method: Two vignettes focused on illness in adults: half of responders completed a vignette about cough and sore throat for 3 days, and the other half completed a vignette about diarrhoea and vomiting for 2 days. Logistic regression was undertaken to identify characteristics associated with contacting GPs compared with dealing with the problem themselves, calling NHS 111, or contacting another service, including a pharmacist.
\end{abstract}

Results: The response rate was 42\%, with 2906 responders. Responders were twice as likely to select 'contact GP' for the diarrhoea and vomiting vignette than for the cough and sore throat vignette (44.7\% versus $21.8 \%)$. Factors associated with tendency for GP contact included being aged $>75$ years (odds ratio [OR] 2.0, 95\% confidence interval $[\mathrm{Cl}]=1.2$ to 3.2); from black, Asian and minority ethnic (BAME) communities (OR 2.1, 95\% Cl = 1.5 to 3.0); feeling overwhelmed by unexpected health problems (OR 1.4, 95\% Cl = 0.99 to 2.1); lower health literacy (OR 1.2, 95\% Cl= 1.0 to 1.4); and believing that general practice is not overused (OR $1.3,95 \% \mathrm{Cl}=1.1$ to 1.7 ).

*For correspondence: a. ocathain@sheffield.ac.uk

Competing interest: The authors declare that no competing interests exist.

Received: 28 November 2019 Accepted: 05 December 2019 Published: 16 April 2020

@This article is Open Access: CC BY license (https://creativecommons.org/licenses/ by/4.0/)

Author Keywords: general practice, heathcare-seeking behaviour, healthcare utilisation, patients, health surveys

Copyright (C) 2020, The Authors; DOI:10.3399/

bjgpopen20X101024
Conclusion: Type of symptom, personal characteristics, and population beliefs about general practice utilisation explain the tendency to contact GPs for minor illness amenable to self-care.

\section{How this fits in}

Clinical workload in general practice is increasing. People contact GPs with minor illnesses that could be addressed using self-care, or advice from NHS 111 or a pharmacist. Addressing low levels of health literacy generally and for specific symptoms may be worth pursuing as interventions to reduce contacts with GPs for minor illnesses.

\section{Introduction}

Clinical workload in primary care in the UK is increasing. ${ }^{1}$ The number of GPs per 100000 population may be decreasing. ${ }^{2}$ Only $62 \%$ of patients seeking a same-day appointment in 2018 received one. ${ }^{3}$ Any mismatch between supply and demand can be addressed by increasing supply of general practice or by reducing demand. It is estimated that millions of general practice contacts annually in the UK are 
for minor illnesses that could be dealt with at community pharmacies. ${ }^{4}$ These types of contacts with general practice may be labelled 'inappropriate'. ${ }^{5}$ This term is best avoided because it does not reflect the moral dilemma faced by patients in their help-seeking, ${ }^{6}$ and the challenges faced by patients as they attempt to take responsibility for their health, while not being judged as wasting the time of a service. ${ }^{7}$ Judgments about the necessity of service use are also fraught with difficulty because of concerns that some patients do not contact general practice when they have serious symptoms, ${ }^{8}$ and the fact that judgments regarding legitimate reasons for service use may vary between individual health professionals. ${ }^{4,9}$

There is evidence that people prefer to look after minor ailments themselves or visit a pharmacy, ${ }^{10,11}$ and contact a GP for more serious symptoms. ${ }^{10,12}$ Yet there is still scope for reducing contacts with GPs for minor illnesses. ${ }^{4}$ Identifying the characteristics of people who choose to contact GPs for minor illnesses instead of self-care may help to identify interventions to reduce this type of demand for general practice. People contacting a GP will seek a same-day (urgent) appointment or a booked (routine) appointment. Demand for same-day appointments can be classed as demand for urgent care. As part of a wider study of demand for emergency and urgent care, a population survey was undertaken to identify attitudes to help-seeking when faced with an unexpected health problem that was not life threatening. ${ }^{13}$ Vignettes were used to explore tendency to contact different services for minor illnesses and injuries. In the analysis reported here, the aim was to identify influences on tendency to contact a GP for minor illnesses compared with self-care options.

\section{Method}

\section{Design}

The study design was a cross-sectional population survey that included vignettes.

\section{Survey sampling}

NatCen Social Research conduct an annual survey in Great Britain called the British Social Attitudes Survey to measure the social attitudes of the population. ${ }^{14}$ The survey is designed to yield a representative sample of adults aged $\geq 18$ years. In 2018 NatCen undertook a multi-stage design in three stages. Great Britain is divided geographically into approximately 9000 postcode sectors. First, NatCen selected 395 postcode sectors with probability proportional to the number of addresses in each sector. Second, they selected 26 addresses in each sector to produce 10270 addresses. Third, interviewers called at each address and listed all those aged $\geq 18$ years before randomly selecting one adult to interview. For practical reasons, the sample was confined to those living in private households; people living in institutions were excluded.

The sample was divided into four parts where each part (of around 1000 responders) was nationally representative in its own right. The University of Sheffield used funding from the National Institute for Health Research to purchase a set of questions in three parts of the survey, that is, a sample size of around 3000 . This sample size was chosen because it offered sufficient statistical power for sub-group analyses.

\section{Mode of administration}

The mode of administration was face-to-face computer assisted interviews. Before calling at the address, a letter including an unconditional incentive (a Post Office voucher) was sent to each selected address informing residents that an interviewer would visit. Interviewers then visited and completed most of the questionnaire face-to-face. A small number of questions were asked through a self-completed paper questionnaire collected by the interviewer or posted by the responder. Data collection was undertaken July 2018-November 2018.

\section{Questionnaire}

The 2018 questionnaire covered a range of topics. A 60-item module exploring population views of help-seeking for unexpected health problems that were not life-threatening was purchased. Items were based on: a realist review; ${ }^{15}$ early findings from a qualitative interview study, with three subgroups of the population who were identified as having a higher tendency to contact emergency and urgent care services when this was not clinically necessary; and a workshop with 13 members of the 
public where potential questions were presented and discussed in small groups. NatCen undertook two consecutive pilots of draft questionnaires on around 50 members of the public before finalising the questionnaire.

\section{Primary outcome}

Three pairs of vignettes were constructed in conjunction with a GP and an emergency department consultant. Each responder completed one vignette from each pair. The vignettes described situations that people might face, and a set of options they could take. One pair of vignettes focused on illness in adults: imagine you have had a cough and sore throat for 3 days; imagine you have had diarrhoea and vomiting for 2 days. The two clinicians considered it clinically unnecessary to call an ambulance, attend an accident and emergency (A\&E) department, or contact a GP for these symptoms. This conclusion was confirmed by the NHS Choices website, a national resource for patients (https://www.nhs.uk), which describes self-care as usually adequate for these symptoms. The following options were offered to responders, ordered by level of urgency: call 999 for an ambulance; go to the A\&E department; contact a GP (for telephone advice or an appointment, including GP 'out-of-hours' service); go to another NHS service, for example, walk-in centre, minor injury unit, pharmacy, or chemist; call NHS 111; deal with the problem myself; and none of these. Because responders could select more than one option, the study compared responders selecting GP contact as their highest urgency option for the vignettes and compared them with responders selecting dealing with the problem themselves, contacting NHS 111, or contacting another NHS service, including a pharmacist, as one of their highest urgency options.

Table 1 Factors tested in the regression

\begin{tabular}{|c|c|c|}
\hline $\begin{array}{l}\text { Sociodemographic, } \\
\text { socioeconomic, and health }\end{array}$ & Programme theories from realist review & Other issues from literature \\
\hline $\begin{array}{l}\text { 1. Age group } \\
\text { 2. Sex } \\
\text { 3. Ethnic group } \\
\text { 4. Geographical region } \\
\text { 5. Household with children } \\
\text { aged }<5 \text { years } \\
\text { 6. Social class (based on } \\
\text { the Standard Occupational } \\
\text { Classification from the UK } \\
\text { Office Of National Statistics) } \\
\text { 7. Social deprivation quintiles } \\
\text { (measured using Index of } \\
\text { Multiple Deprivation }{ }^{16} \text { ) } \\
\text { 8. Urban/rural status } \\
\text { 9. Personal access to internet } \\
\text { 10. Car ownership } \\
\text { 11. Presence of limiting long- } \\
\text { term illness } \\
\text { 12. General health }\end{array}$ & $\begin{array}{l}\text { Uncertainty causes anxiety. Items: } \\
\text { 1. Worry pain is a sign of something serious. } \\
\text { 2. Not confident in deciding when to see a doctor. }{ }^{\text {a }} \\
\text { Previous traumatic event. Item: } \\
\text { 3. Did not see doctor in past when the health problem was } \\
\text { serious. } \\
\text { Need to get back to normal. Items: } \\
\text { 4. Seeks help if problem causes sleep loss. } \\
\text { 5. Seeks help if problem impacts on work. } \\
\text { Seeking pain relief. Item: } \\
\text { 6. Does not take medication to stop pain. } \\
\text { Stressful lives cause difficulty coping so low burden services } \\
\text { sought. Items: } \\
\text { 7. Feel overwhelmed when have a health problem. } .^{\text {a }} \\
\text { 8. Find life stressful. } \\
\text { 9. Has no one to care for them if ill. }{ }^{\text {a }} \\
\text { 10. Difficulty taking time off work to see a GP. } \\
\text { 11. Ease of travel to an emergency department. } \\
\text { 12. Opening hours of health services problematic. }{ }^{a} \\
\text { 13. Preference for services with no appointments. } \\
\text { 14. Desire for services open at times convenient to them. }{ }^{a} \\
\text { 15. Willingness to wait in a waiting room to be seen that day. } \\
\text { Follow advice of trusted others. Item: } \\
\text { 16. Check what to do with family and friends. } \\
\text { Prustration with access to GP. Items: } \\
\text { 20. Ease or difficulty getting GP appointment. } \\
\text { 21. Whether registered with GP. } \\
\text { 22. Whether responsibilities make it difficult to see a GP. } \\
\text { 23. Belief that people use emergency departments because } \\
\text { they can't get a GP appointment. } \\
\text { tests done quickly. }{ }^{a} \\
\text { 18. Beliefs about emergency department doctors knowing } \\
\text { more than GPs. } \\
\text { 19. No confidence in their GP.a } \\
\end{array}$ & $\begin{array}{l}\text { Awareness of services. Items: } \\
\text { 1. Confidence in knowing the range of services available. } \\
\text { 2. Confidence in finding opening times of services. } \\
\text { 3. Confidence in knowing what tests are available where. } \\
\text { 4. Confidence in how to contact a GP out of hours. } \\
\text { 5. Likelihood of looking up a problem on the internet. } \\
\text { 6. Likelihood of looking up where to go on the internet. } \\
\text { Recursivity and/or learnt behaviour. }{ }^{17} \text { Item: } \\
\text { 7. See having tests done as validating attendance at a } \\
\text { service. } \\
\text { Health literacy, measured using the Health Literacy } \\
\text { Questionnaire. }{ }^{18} \text { Two of the } 9 \text { domains of this instrument } \\
\text { were used, each } 5 \text { items long. Items: } \\
\text { 8. Ability to communicate with health professionals. }{ }^{\text {a }} \\
\text { 9. Ability to understand health information. }{ }^{\mathrm{a}} \\
\text { Recent use of services for self or others. Items: } \\
\text { 10. When last used emergency ambulance. } \\
\text { 11. Frequent use of ambulance. } \\
\text { 12. When last used emergency department. } \\
\text { 13. Frequent use of emergency department. } \\
\text { 14. When last used GP. } \\
\text { Perceptions of service overuse. Items: } \\
\text { 15. Beliefs that too many people use } 999 \text { ambulance } \\
\text { unnecessarily. } \\
\text { 16. Too many people use emergency departments. } \\
\text { 17. Too many people use GP. } \\
\text { 18. People are reluctant to use emergency departments. }\end{array}$ \\
\hline
\end{tabular}

จVariable on self-completed part of questionnaire. 


\section{Factors tested}

Fifty-three factors were tested. These factors were described in three categories for ease of reading (Table 1), although all factors were tested together. There were 12 sociodemographic, socioeconomic, and health items. There were 23 items measuring programme theories potentially explaining clinically unnecessary use of emergency and urgent care, which were derived from a realist review undertaken for the wider study. ${ }^{15}$ These programme theories were supported by theories of health behaviour, including Leventhal et al's common sense model ${ }^{19}$ and Andersen's healthcare utilisation model. ${ }^{20}$ There were 18 items measuring other issues potentially affecting clinically unnecessary use of emergency and urgent care, which were identified from the wider literature. These issues did not feature strongly enough in the realist review to be identified as programme theories.

\section{Analysis}

For the vignettes, a binary variable was created based on whether responders chose to contact a GP versus self-care; that is, chose to deal with the problem alone, contact NHS 111 (a 24-hour urgent telephone helpline), or contact another NHS service, including a pharmacist. Options of contacting an emergency ambulance, attending an emergency department, and other options, such as 'don't know', were excluded from the analysis.

IBM SPSS Statistics software (version 25) was used for the logistic regression. First, prior to starting the regression, some categories of some variables were collapsed where numbers were small. Second, a univariate analysis was conducted, testing each of the 53 independent variables. Third, the statistically significant variables from the univariate analysis were tested (where $P<0.05$ ) in a complete case multivariable logistic regression, using backwards elimination with a cut off of 0.05 for selection. Backwards elimination has advantages over forward selection when variables are correlated. ${ }^{21}$ As the level of missing data was low (apart from the missing values for self-completion questions), missing data were treated as missing and no methods of imputation were used. Fourth, differences by vignettes were tested by testing interaction terms between vignettes completed and each of the factors in the final multivariable model. The results are presented as ORs with $95 \% \mathrm{Cls}$.

\section{Results}

\section{Response rate and non-response bias}

The overall survey response was $42 \%$, with 2906 responders completing the module during face-toface administration. Only 2309 (79.5\%) of those interviewed returned the self-completed part of the questionnaire. There was non-response bias. Response was higher where there were no barriers to entry such as locked gates, if the general condition of the address was better than other addresses in the area, and for flats rather than detached houses. ${ }^{14}$

\section{Description of sample}

The characteristics of the full sample are displayed in Table 2. For example, $13.9 \%$ of the sample were aged $\geq 75$ years or older and $11.5 \%$ were from BAME communities.

\section{Tendency to contact GP versus self-care}

Responses to the vignettes are shown in Table 3. The first two columns show how all 2906 responders completed the vignettes. The second two columns show responses for those included in the logistic regression. Responders were twice as likely to select 'contact a GP' for the diarrhoea and vomiting vignette than for the cough and sore throat vignette, and they were more likely to call NHS 111.

\section{Factors explaining tendency to contact a GP}

The 926 (34.0\%) responders who ticked 'contact a GP' were compared with the 1796 (66.0\%) who ticked a self-care option (other NHS service including a pharmacist, call NHS 111, deal with it themselves), totalling 2722 responders. Factors with $P<0.05$ in the univariate analysis are displayed in Tables 4-6, for the socio-demographic factors see Table 4, for programme theories see Table 5 and other issues see Table 6. Factors for the complete case analysis of 2148 responders in the final multivariable model are displayed in Tables 4-6. 
Table 2 Characteristics of the survey sample, $N=2906$.

\begin{tabular}{|c|c|c|}
\hline Variable & $n(\%)$ & Data missing, $n$ \\
\hline Age, years & & 5 \\
\hline $18-24$ & $169(5.8)$ & \\
\hline $25-34$ & $384(13.2)$ & \\
\hline $35-44$ & $467(16.1)$ & \\
\hline $45-54$ & $469(16.2)$ & \\
\hline $55-64$ & $508(17.5)$ & \\
\hline $65-74$ & $499(17.2)$ & \\
\hline$\geq 75$ & $405(14.0)$ & \\
\hline Sex & & 0 \\
\hline Male & $1257(43.3)$ & \\
\hline Female & $1649(56.7)$ & \\
\hline Ethnic group & & 0 \\
\hline White origin & $2572(88.5)$ & \\
\hline Black Asian and minority ethnic (BAME) communities & $334(11.5)$ & \\
\hline Social class ${ }^{\mathrm{a}}$ & & 92 \\
\hline 1 & $214(7.6)$ & \\
\hline$\underline{\|}$ & 1039 (36.9) & \\
\hline III (non-manual) & $569(20.2)$ & \\
\hline III (manual) & $416(14.8)$ & \\
\hline $\mathrm{IV} / \mathrm{V}$ & $524(18.6)$ & \\
\hline Armed Forces & $52(1.8)$ & \\
\hline Urban/rural categorisation & & 0 \\
\hline Urban & $2241(77.1)$ & \\
\hline Rural & $665(22.9)$ & \\
\hline Long-term limiting illness & & 0 \\
\hline None & $1766(60.8)$ & \\
\hline Non-limiting & $586(20.2)$ & \\
\hline$\underline{\text { Limiting }}$ & $541(18.6)$ & \\
\hline Don't know, refusal & $13(0.4)$ & \\
\hline General health $^{b}$ & & 597 \\
\hline Excellent & $223(9.7)$ & \\
\hline Very good & $725(31.4)$ & \\
\hline Good & $799(34.6)$ & \\
\hline Fair & $360(15.6)$ & \\
\hline Poor & $163(7.1)$ & \\
\hline Can't choose or not answered & $39(1.7)$ & \\
\hline
\end{tabular}

aBased on the Standard Occupational Classification from the UK Office Of National Statistics. ${ }^{b}$ Self-completed. 
Table 3 Percentages of sample selecting options for minor illness vignettes. ${ }^{a}$

\begin{tabular}{|c|c|c|c|c|c|}
\hline & $\begin{array}{l}\text { All responders, } \\
\qquad n=1471\end{array}$ & $\begin{array}{l}\text { All responders, } \\
\quad n=1435\end{array}$ & $\begin{array}{l}\text { Included in logistic } \\
\text { regression, } \\
n=1395\end{array}$ & $\begin{array}{l}\text { Included in logistic } \\
\text { regression, } \\
n=1327\end{array}$ & $\begin{array}{c}\text { Categorisation of GP } \\
\text { contact versus self- } \\
\text { care }\end{array}$ \\
\hline & $\begin{array}{c}\text { Cough and sore } \\
\text { throat, } \\
\text { n (\%) }\end{array}$ & $\begin{array}{l}\text { Diarrhoea and } \\
\text { vomiting, } \\
\text { n (\%) }\end{array}$ & $\begin{array}{c}\text { Cough and sore } \\
\text { throat, } \\
n(\%)\end{array}$ & $\begin{array}{c}\text { Diarrhoea and } \\
\text { vomiting, } \\
n(\%)\end{array}$ & \\
\hline Call 999 for an ambulance & $4(0.3)$ & $22(1.5)$ & - & - & \\
\hline Go to the A\&E department & $17(1.2)$ & $73(5.1)$ & - & - & \\
\hline $\begin{array}{l}\text { Contact a GP (for telephone } \\
\text { advice or an appointment, } \\
\text { including GP 'out-of-hours' } \\
\text { service) }\end{array}$ & $320(21.8)$ & $641(44.7)$ & $311(22.3)$ & $615(46.3)$ & GP contact \\
\hline $\begin{array}{l}\text { Go to another NHS service, } \\
\text { for example, walk-in centre, } \\
\text { minor injury unit, pharmacy, } \\
\text { or chemist }\end{array}$ & $262(17.8)$ & $260(18.1)$ & $256(18.4)$ & $246(18.5)$ & Self-care \\
\hline Call NHS 111 & $42(2.9)$ & $229(16.0)$ & $37(2.7)$ & $216(16.3)$ & Self-care \\
\hline Deal with the problem myself & $1026(69.7)$ & $693(48.3)$ & $1024(73.4)$ & $681(51.3)$ & Self-care \\
\hline None of these & $45(3.1)$ & $14(1.0)$ & - & - & \\
\hline $\begin{array}{l}\text { Refusal or don't know or } \\
\text { missing }\end{array}$ & $10(0.7)$ & $7(0.5)$ & - & - & \\
\hline
\end{tabular}

Multiple options could be selected; therefore, percentages add to more than 100.

Seven of the 12 sociodemographic factors were statistically signficant (Table 4). Surprisingly, deprivation was not associated with a tendency to contact a GP for these minor illnesses in the univariate analysis. In the multivariable analysis, older people and people from BAME communities had a greater tendency to contact a GP.

Thirteen of the 23 programme theory factors were statistically significant in the univariate analysis (see Table 5). Surprisingly, participants' views of how difficult it was to get an appointment with a GP, and levels of confidence in their GP, were not associated with tendency to contact a GP for these minor illnesses in the univariate analysis. In the multivariable analysis, participants who selected 'contact a GP' were more likely to worry that symptoms were serious, feel overwhelmed when faced with an unexpected health problem, and have personal circumstances that made it easy to see a GP. In the sample in the logistic regression, $44.0 \%(n=1197 / 2722)$ worried that pain was a sign of something serious, $13.0 \%$ ( $n=285 / 2190)$ felt overwhelmed when faced with a health problem, and $17.7 \%(n=$ $388 / 2190$ ) had personal circumstances that made it difficult to see a GP.

Fifteen of the 18 other issues were statistically significant in the univariate analysis (see Table 6). For other issues in the multivariable analysis, participants who selected 'contact a GP' were more likely to believe that a service doing tests on them was a sign they were right to seek help (an indicator of recursivity), have lower levels of health literacy, have recently used general practice, and believe that people do not overuse general practice. Responses show that $53.1 \%(n=1163 / 2190)$ of the population felt that if tests were done they were right to contact a service, and $27.6 \%(n=752 / 2722)$ did not believe that general practice was overused.

There were only two statistically significant interactions between the factors in the multivariable analysis and the vignette completed: age and recursivity. This indicates that the results generally are not dependent on the vignette completed.

\section{Discussion}

\section{Summary}

A tendency to contact a GP rather than undertake a self-care option was symptom dependent. Responders were twice as likely to select 'contact a GP' for diarrhoea and vomiting than for cough and sore throat. Tendency was also related to personal characteristics, including sociodemographics (older people and people from BAME communities), ability to cope with unexpected illness, and health 
Table 4 Sociodemographic characteristics of tendency to contact GP rather than self-care for minor illness.

\begin{tabular}{|c|c|c|c|c|}
\hline Variables & $\begin{array}{c}\text { Univariate }(N=2722), \\
\text { OR }(95 \% \mathrm{Cl}), n\end{array}$ & $P$ value & $\begin{array}{c}\text { Final multivariable } \\
\text { model }(N=2148), \\
\text { OR }(95 \% \mathrm{Cl}), n\end{array}$ & $P$ value \\
\hline Age, years & & $<0.001$ & & $<0.001$ \\
\hline $18-24$ & 1.0 (ref), 158 & & 1.0 (ref), 123 & \\
\hline $25-34$ & 1.0 (0.7 to 1.5$), 348$ & & 1.0 (0.6 to 1.6$), 269$ & \\
\hline $35-44$ & 0.9 (0.6 to 1.4$), 437$ & & 0.8 (0.5 to 1.3$), 327$ & \\
\hline $45-54$ & 0.8 (0.6 to 1.2$), 446$ & & 0.9 (0.5 to 1.4$), 361$ & \\
\hline $55-64$ & 1.1 (0.7 to 1.6$), 484$ & & 1.3 (0.8 to 2.1$), 393$ & \\
\hline $65-74$ & 1.4 (0.96to 2.1$), 468$ & & 1.4 (0.9 to 2.1$), 397$ & \\
\hline$\geq 75$ & 2.0 (1.4 to 3.0$), 376$ & & 2.0 (1.2 to 3.2$), 278$ & \\
\hline Data missing, $n$ & 5 & & - & \\
\hline Ethnic group & & $<0.001$ & & $<0.001$ \\
\hline White & 1.0 (ref), 2439 & & 1.0 (ref), 1967 & \\
\hline BAME & 1.7 (1.3 to 2.2$), 283$ & & 2.1 (1.5 to 3.0$), 181$ & \\
\hline Data missing, $n$ & 0 & & - & \\
\hline Region & & 0.041 & & \\
\hline North England & 1.0 (ref), 449 & & & \\
\hline Midlands & 1.1 (0.8 to 1.4$), 738$ & & & \\
\hline South England & 1.3 (0.99 to 1.6$), 897$ & & & \\
\hline London & 1.5 (1.1 to 2.0$), 262$ & & & \\
\hline Wales & 1.4 (0.9 to 2.1$), 127$ & & & \\
\hline Scotland & 1.4 (1.0 to 2.0$), 249$ & & & \\
\hline Data missing, $n$ & 0 & & & \\
\hline Car ownership & & 0.004 & & \\
\hline$\geq 1$ & 1.0 (ref), 1388 & & & \\
\hline None & 1.5 (1.2 to 1.9$), 395$ & & & \\
\hline Not asked ${ }^{a}$ & 1.1 (0.9 to 1.3$), 939$ & & & \\
\hline Data missing, $n$ & 0 & & & \\
\hline $\begin{array}{l}\text { Personal access to } \\
\text { internet }^{a}\end{array}$ & & $<0.001$ & & \\
\hline Yes & 1.0 (ref), 2393 & & & \\
\hline No & 1.8 (1.5 to 2.3$), 329$ & & & \\
\hline Data missing, $n$ & 0 & & & \\
\hline General health & & $<0.001$ & & \\
\hline Excellent & 1.0 (ref), 207 & & & \\
\hline Very good & 1.0 (0.7 to 1.3$), 695$ & & & \\
\hline Good & 1.2 (0.9 to 1.7$), 763$ & & & \\
\hline Fair & 1.4 (0.96 to 2.0$), 339$ & & & \\
\hline Poor & 1.8 (1.2 to 2.8$), 151$ & & & \\
\hline Can't choose & 2.2 (1.0 to 4.5$), 35$ & & & \\
\hline
\end{tabular}


Table 4 Continued

\begin{tabular}{|c|c|c|c|c|}
\hline Variables & $\begin{array}{c}\text { Univariate }(N=2722), \\
\text { OR }(95 \% \mathrm{Cl}), n\end{array}$ & $P$ value & $\begin{array}{c}\text { Final multivariable } \\
\text { model }(N=2148), \\
\text { OR }(95 \% \mathrm{Cl}), n\end{array}$ & $P$ value \\
\hline Data missing, $n$ & 532 & & & \\
\hline Long-term limiting illness & & 0.004 & & \\
\hline None & 1.0 (ref), 1656 & & & \\
\hline Non-limiting & 1.0 (0.8 to 1.3$), 556$ & & & \\
\hline Limiting & 1.4 (1.1 to 1.7$), 503$ & & & \\
\hline Do not know & 5.2 (1.0 to 27.0$), 7$ & & & \\
\hline Data missing, $n$ & 0 & & & \\
\hline
\end{tabular}

${ }^{a}$ One of the four samples used by NatCen did not ask about car ownership. BAME = black, Asian, and minority ethnic. $O R=$ odds ratio.

literacy levels, and finally with beliefs concerning the actions services took for previous problems (recursivity) and about overuse of general practice.

\section{Strengths and limitations}

A wide range of factors were tested, which were based on factors identified in the literature as affecting use of emergency and urgent care for minor ailments and in qualitative interviews with users of ambulance, emergency departments, and same-day general practice. There were three limitations: first, there was non-response bias and the sample did not include people living in residential or nursing homes; therefore, some demographics of older people were not represented. NatCen produced weights to ensure the sample was representative of the British population, but these weights could not be used in the type of analysis that was undertaken. Second, the vignette approach identifies tendency rather than actual use of services and it is possible that people may act differently in practice. Third, the options for vignettes did not include contact with a nurse or other clinician at general practice.

\section{Comparison with existing literature}

The majority of responders in the study selected self-care options for the cough and sore throat vignette. This is supported by evidence that people prefer to look after minor ailments themselves, ${ }^{10,11}$ however, this was not the case for the diarrhoea and vomiting vignette, indicating that behaviour is symptom dependent.

The prevalence of some of the factors tested was similar to those found in previous research. The majority of the responders felt that too many people use general practice when they do not need to (72.4\%), compared with $66 \%$ in a 2003 survey of a general practice population who felt that people use emergency departments or a GP inappropriately. ${ }^{22}$ Some of the factors that were identified as explaining tendency to use a GP for minor illness were similar to a vignette study in a single UK general practice, where concern that a symptom was a sign of something serious explained help-seeking. ${ }^{22}$

It was found that lower health literacy explained tendency to contact a GP for minor illness and this is supported by a study of factors determining parental reassurance for a child with fever in rural general practice. ${ }^{23}$ Parents who lacked knowledge about complications of fever had higher levels of concern before consulting a doctor and were less likely to be reassured after consultation with a doctor, leading to a recommendation that further education of parents is required. ${ }^{23}$

The present study's findings were supported by theories of help-seeking behaviour and primary research on help-seeking in general practice. People who worry that pain is a sign of something serious are displaying anxiety. Anxiety plays a central role in decision making when managing illness, ${ }^{19,24}$ where patients determine the amount of threat posed by a symptom by thinking about what it might be, how long it should last, what might be causing it, and the potential consequences. Similarly, feeling overwhelmed is a sign of lack of coping and this has been identified as a predisposing factor to healthcare utilisation. ${ }^{20}$ There may be some support for the finding about people from BAME communities in the concept of 'temporalising', where people decide to wait for a specified amount 
Table 5 Factors measuring programme theories: association with tendency to contact GP rather than self-care for minor illness.

\begin{tabular}{|c|c|c|c|c|}
\hline Variables & $\begin{array}{l}\text { Univariate }(N=2722) \\
\text { OR }(95 \% \mathrm{Cl}), n\end{array}$ & $P$ value & $\begin{array}{c}\text { Final multivariable } \\
\text { model } \\
(N=2148), \text { OR }(95 \% \\
\mathrm{Cl}), n\end{array}$ & $P$ value \\
\hline $\begin{array}{l}\text { Worry pain is a sign of something } \\
\text { serious }\end{array}$ & & $<0.001$ & & $<0.001$ \\
\hline Not likely at all & 1.0 (ref), 337 & & 1.0 (ref), 261 & \\
\hline Not very likely & 1.3 (0.99 to 1.8$), 1087$ & & 1.3 (0.9 to 1.8$), 873$ & \\
\hline Fairly likely & $1.9(1.5$ to 2.6$), 813$ & & $1.8(1.2$ to 2.5$), 643$ & \\
\hline Very likely & $2.9(2.1$ to 4.0$), 384$ & & $2.1(1.4$ to 3.1$), 299$ & \\
\hline It depends & 1.4 (0.9 to 2.3$), 101$ & & 1.3 (0.7 to 2.4$), 72$ & \\
\hline Data missing, $n$ & 0 & & - & \\
\hline $\begin{array}{l}\text { Confident in deciding when to see a } \\
\text { doctor or self-care }\end{array}$ & & 0.024 & & \\
\hline Very confident & 1.0 (ref), 947 & & & \\
\hline Fairly & 1.2 (0.99 to 1.4$), 1070$ & & & \\
\hline Not very confident & $1.1(0.7$ to 1.9$), 79$ & & & \\
\hline Never had problem & 1.9 (1.2 to 2.9$), 94$ & & & \\
\hline Data missing, $n$ & 532 & & & \\
\hline Affecting sleep & & $<0.001$ & & \\
\hline Will not contact GP & 1.0 (ref), 1905 & & & \\
\hline See doctor only if sleep loss & 1.7 (1.4 to 2.1$) 586$ & & & \\
\hline See doctor if any loss of function & 2.4 (1.8 to 3.2$) 231$ & & & \\
\hline Data missing, $n$ & 0 & & & \\
\hline Affecting work ${ }^{\mathrm{a}}$ & & $<0.001$ & & \\
\hline Will not contact GP & 1.0 (ref), 873 & & & \\
\hline See doctor only if work loss & 1.2 (0.98 to 1.4$), 1618$ & & & \\
\hline See doctor if any loss of function & $2.3(1.7$ to 3.1$), 231$ & & & \\
\hline Data missing, $n$ & 0 & & & \\
\hline Likely to take medication to stop pain & & $<0.001$ & & \\
\hline Very likely & 1.0 (ref), 1018 & & & \\
\hline Fairly & 1.0 (0.8 to 1.2$), 1188$ & & & \\
\hline Not very & 0.7 (0.5 to 0.9$), 352$ & & & \\
\hline Not at all & 0.6 (0.4 to 0.9$), 125$ & & & \\
\hline Depends & 1.5 (0.8 to 2.9$), 39$ & & & \\
\hline Data missing, $n$ & 0 & & & \\
\hline $\begin{array}{l}\text { Feel overwhelmed when have health } \\
\text { problem }\end{array}$ & & $<0.001$ & & 0.020 \\
\hline Strongly disagree & 1.0 (ref), 465 & & 1.0 (ref), 462 & \\
\hline Disagree & $1.6(1.2$ to 2.1$), 829$ & & 1.3 (0.99 to 1.7$), 821$ & \\
\hline Neither & 2.3 (1.8 to 3.1$), 515$ & & $1.7(1.2$ to 2.3$), 489$ & \\
\hline Strongly agree or agree & 2.2 (1.6 to 3.0$), 285$ & & $1.4(0.99$ to 2.1$), 283$ & \\
\hline Never had problem & $2.0(1.2$ to 3.2$), 96$ & & 1.7 (1.0 to 2.8$), 93$ & \\
\hline Data missing, $n$ & 532 & & - & \\
\hline Can take time off work for GP & & $<0.001$ & & \\
\hline
\end{tabular}

Can take time off work for GP 
Table 5 Continued

Variables
Yes
Yes but not easy
No

Univariate ( $N=2722)$, OR $(95 \% \mathrm{CI}), n$

1.0 (ref), 1024

0.8 (0.6 to 1.1$), 255$

Not applicable or missing

0.7 (0.5 to 1.2$), 115$

Not applicable or missing
Travel to emergency department

1.6 (1.4 to 1.9$), 1328$

Very difficult

$<0.001$

Neither

1.0 (ref), 572

Fairly easy

1.1 (0.8 to 1.5$), 243$

Very easy

0.8 (0.6 to 0.98$), 1099$

Data missing, $n$

$0.6(0.5$ to 0.7$), 808$

\section{Prefer no appointments}

0

Disagree or strongly disagree

0.010

Neither

1.0 (ref), 650

Strongly agree or agree

1.2 (0.9 to 1.5$), 765$

Data missing, $n$

1.4 (1.1 to 1.8$), 775$

532

Willing to wait in waiting room to be

seen

$<0.001$

Disagree or strongly disagree

1.0 (ref), 341

Neither

1.7 (1.1 to 2.5$), 164$

Strongly agree or agree

1.7 (1.3 to 2.2$), 2217$

Data missing, $n$

0

\section{Check with family and friends for what}

to do

$<0.001$

Not very likely

1.0 (ref), 507

Not likely

$1.2(0.96$ to 1.6$), 695$

Fairly likely

1.4 (1.1 to 1.8$), 1005$

Very likely

1.8 (1.4 to 2.3$), 515$

Data missing, $n$

0

Prefer ED for quick tests

0.004

Disagree or strongly disagree

1.0 (ref), 1109

Neither

1.2 (0.99 to 1.5$), 760$

Agree or strongly agree

1.5 (1.2 to 2.0$), 321$

Data missing, $n$

532

Work or looking after family makes it
difficult to see GP

Disagree or strongly disagree

0.004

0.041

Neither

1.0 (ref), 1134

1.0 (ref), 1129

Strongly agree or agree

$1.0(0.8$ to 1.2$), 432$

$0.8(0.6$ to 1.1$), 403$

Not applicable

0.6 (0.5 to 0.8$), 388$

0.7 (0.5 to 0.9$), 386$

Data missing, $n$

1.1 (0.8 to 1.4$), 236$

0.8 (0.6 to 1.1$), 230$

532

$\mathrm{ED}=$ emergency department. $\mathrm{OR}=$ odds ratios. 
Table 6 Factors measuring other issues from literature: association with tendency to contact GP rather than self-care for minor illness.

\begin{tabular}{|c|c|c|}
\hline Variables & $\begin{array}{l}\text { Univariate }(N=2722) \\
\text { OR }(95 \% \mathrm{Cl}), n\end{array}$ & $\begin{array}{c}\text { Final multivariable model }(N= \\
2148), \\
\text { OR }(95 \% \mathrm{Cl}), n\end{array}$ \\
\hline \multicolumn{3}{|l|}{ Awareness of services } \\
\hline Know range of NHS services to use & 0.007 & \\
\hline Very confident & 1.0 (ref), 1366 & \\
\hline Fairly confident & $1.2(1.0$ to 1.4$), 1113$ & \\
\hline Not confident or not at all & 1.5 (1.1 to 2.0$), 243$ & \\
\hline Data missing, $n$ & 0 & \\
\hline Can find out when NHS services are open & 0.001 & \\
\hline Very confident & 1.0 (ref), 1412 & \\
\hline Fairly confident & $1.3(1.1$ to 1.5$), 1089$ & \\
\hline Not confident or not at all & $1.6(1.2$ to 2.1$), 221$ & \\
\hline Data missing, $n$ & 0 & \\
\hline $\begin{array}{l}\text { Can find out what tests are available at NHS } \\
\text { services }\end{array}$ & 0.031 & \\
\hline Very confident & 1.0 (ref), 913 & \\
\hline Fairly confident & $1.2(1.0$ to 1.5$), 1224$ & \\
\hline Not confident or not at all & $1.3(1.1$ to 1.6$), 585$ & \\
\hline Data missing, $n$ & 0 & \\
\hline Know how to contact GP out of hours & 0.007 & \\
\hline Very confident & 1.0 (ref), 1262 & \\
\hline Fairly confident & $1.3(1.1$ to 1.6$), 1001$ & \\
\hline Not very confident & 1.4 (1.1 to 1.8$), 358$ & \\
\hline Not at all & 1.2 (0.8 to 1.8$), 101$ & \\
\hline Data missing, $n$ & 0 & \\
\hline Will look up on internet to see what to do & 0.002 & \\
\hline Very likely & 1.0 (ref), 406 & \\
\hline Fairly likely & 0.9 (0.7 to 1.2$), 708$ & \\
\hline Not very likely & 1.1 (0.9 to 1.5$), 639$ & \\
\hline Not at all & 1.3 (1.0 to 1.6$), 952$ & \\
\hline Do not know or never had problem & 3.1 (1.1 to 8.2$), 17$ & \\
\hline Data missing, $n$ & 0 & \\
\hline $\begin{array}{l}\text { Will look up on internet to decide what } \\
\text { problem is }\end{array}$ & 0.006 & \\
\hline Very likely & 1.0 (ref), 629 & \\
\hline Fairly likely & 1.0 (0.8 to 1.3$), 756$ & \\
\hline Not very likely & $1.2(0.9$ to 1.5$), 434$ & \\
\hline Not at all & 1.3 (1.0 to 1.6$), 887$ & \\
\hline Do not know or never had problem & 3.4 (1.3 to 10.3$), 16$ & \\
\hline Data missing, $n$ & 0 & \\
\hline Recursivity & & \\
\hline
\end{tabular}


Table 6 Continued

\begin{tabular}{|c|c|c|}
\hline Variables & $\begin{array}{l}\text { Univariate }(N=2722) \\
\text { OR }(95 \% \mathrm{Cl}), n\end{array}$ & OR $(95 \% \mathrm{CI}), n$ \\
\hline $\begin{array}{l}\text { If tests are done I was right to contact a } \\
\text { service }\end{array}$ & $<0.001$ & 0.003 \\
\hline Disagree or strongly disagree & 1.0 (ref), 261 & 1.0 (ref), 259 \\
\hline Neither & $1.9(1.3$ to 2.6$), 766$ & 1.5 (1.1 to 2.2$), 734$ \\
\hline Agree or strongly agree & 2.5 (1.8 to 3.5$), 1163$ & 1.8 (1.3 to 2.5$), 1155$ \\
\hline Data missing, $n$ & 532 & - \\
\hline \multicolumn{3}{|l|}{ Health literacy } \\
\hline $\begin{array}{l}\text { Lower health literacy compared with high } \\
\text { health literacy: understand information }\end{array}$ & $\begin{array}{c}<0.001 \\
1.4(1.2 \text { to } 1.6), 2153\end{array}$ & $\begin{array}{c}0.013 \\
1.2(1.0 \text { to } 1.4), 2148\end{array}$ \\
\hline Data missing, $n$ & 569 & - \\
\hline $\begin{array}{l}\text { Lower health literacy compared with high } \\
\text { health literacy: ability to communicate with } \\
\text { professionals }\end{array}$ & $\begin{array}{c}0.02 \\
1.2(1.0 \text { to } 1.3), 2153\end{array}$ & \\
\hline Data missing, $n$ & 569 & \\
\hline \multicolumn{3}{|l|}{ Recent use of health care } \\
\hline Ambulance frequency of use & 0.024 & \\
\hline $0-3$ times in past 12 months & 1.0 (ref), 2664 & \\
\hline$>3$ times in past 12 months & $1.8(1.1$ to 3.1$), 58$ & \\
\hline Data missing, $n$ & 0 & \\
\hline ED use & 0.002 & \\
\hline Never & 1.0 (ref), 366 & \\
\hline$>12$ months & $0.6(0.5$ to 0.8$), 1409$ & \\
\hline 6-12 months & $0.6(0.4$ to 0.8$), 345$ & \\
\hline $3-<6$ months & 0.7 (0.5 to 0.99$), 212$ & \\
\hline$<3$ months & 0.8 (0.6 to 0.99$), 390$ & \\
\hline Data missing, $n$ & 0 & \\
\hline ED frequency of use & 0.039 & \\
\hline $0-3$ times in past 12 months & 1.0 (ref), 2569 & \\
\hline$>3$ times in past 12 months & $1.4(1.0$ to 2.0$), 153$ & \\
\hline Data missing, $n$ & 0 & \\
\hline General practice use & $<0.001$ & 0.012 \\
\hline$>12$ months & 1.0 (ref), 424 & 1.0 (ref), 310 \\
\hline Never & 1.5 (0.8 to 2.8$), 44$ & $1.5(0.7$ to 3.5$), 28$ \\
\hline 6-12 months & 1.5 (1.1 to 2.0$), 448$ & 1.5 (1.1 to 2.2$), 369$ \\
\hline $3-<6$ months & $1.2(0.9$ to 1.6$), 491$ & $1.0(0.7$ to 1.4$), 386$ \\
\hline$<3$ months & 1.7 (1.3 to 2.2$), 1315$ & $1.3(0.99$ to 1.8$), 1055$ \\
\hline Data missing, $n$ & 0 & \\
\hline \multicolumn{3}{|l|}{$\begin{array}{l}\text { Attitudes towards overuse of health } \\
\text { services }\end{array}$} \\
\hline Too many people use GP when not needed & $<0.001$ & 0.042 \\
\hline Agree or strongly disagree & 1.0 (ref), 1970 & 1.0 (ref), 1562 \\
\hline
\end{tabular}


Table 6 Continued

\begin{tabular}{|c|c|c|}
\hline Variables & $\begin{array}{c}\text { Univariate }(N=2722), \\
\text { OR }(95 \% \mathrm{CI}), n\end{array}$ & $\begin{array}{c}\text { Final multivariable model }(N= \\
2148), \\
\text { OR }(95 \% \mathrm{Cl}), n\end{array}$ \\
\hline Neither & $1.4(1.2$ to 1.7$), 523$ & $1.3(1.1$ to 1.7$), 412$ \\
\hline Disagree or strongly disagree & 1.4 (1.1 to 1.9$), 229$ & 1.2 (0.8 to 1.7$), 174$ \\
\hline Data missing, $n$ & 0 & \\
\hline People are reluctant to use EDs when needed & 0.021 & \\
\hline Agree or strongly agree & 1.0 (ref), 1263 & \\
\hline Neither & $0.9(0.7$ to 1.1$), 672$ & \\
\hline Disagree or strongly disagree & 0.8 (0.6 to 0.9$), 787$ & \\
\hline Data missing, $n$ & 0 & \\
\hline
\end{tabular}

$\mathrm{ED}=$ emergency department. $\mathrm{OR}=$ odds ratio

of time before seeking help. In research published over 50 years ago, this was particularly associated with Anglo-Saxon Protestant patients but did not significantly influence other ethnic groups. ${ }^{25}$

\section{Implications for research and practice}

There are four possible policy and practice implications of these results. First, people were more likely to consider contacting a GP with some symptoms than others. This has implications for educating the population about specific common minor illnesses and how best to deal with them. For example, educating the population about the expected length of time diarrhoea and vomiting can last without it being a cause for concern may help to reduce tendency to contact a GP. This fits with a recent qualitative study of GPs in the UK that identified patient education about self-management of minor illness as important to cope with increasing workload in general practice. ${ }^{26}$ One way of addressing patient education is GPs discussing expectations around help-seeking for minor illness with patients during consultations for minor illness, and the alternative actions they can take when next faced with similar symptoms. However, GPs in the UK are already concerned about their workload and so have expressed a preference for the government rather than GPs to be responsible for this education. ${ }^{26}$ This means that education might best occur using national campaigns of leaflets or online resources. Attempts have been made to educate people registered with a GP about minor illness using leaflets. ${ }^{27}$ Although this intervention met with some success, the authors concluded that the costs might outweigh the small gains in reduced consultation rates. ${ }^{27}$ That study was published in 2001 and the results are worth reinterpretation in today's context of increased GP workload and the value of reducing it. It may be worth attempting population-level education about specific symptoms and evaluating the impact of these initiatives. Evaluation could also include assessment of missed serious illnesses given concerns that focusing on reducing GP contacts for minor illnesses might stop some people contacting GPs with serious symptoms.

A second implication of the work is that better attention could be paid to health literacy levels within the population. People with lower health literacy levels had a greater tendency to contact a GP for minor illness. Any leaflets or digital sources of information to educate the population about specific symptoms may not be understood by people with low health literacy. Either information will need to be written for people with low levels of health literacy or interventions will be needed to increase levels of health literacy in the population.

A third implication relates to the finding that some people in the survey felt overwhelmed when faced with an unexpected health problem. Inability to cope with minor illness may be caused by a range of issues such as poverty, stressful work, social isolation, or dealing with chronic illnesses for one's self or family members. Public health interventions may be needed to address these wider social issues.

A final implication relates to the population sub-groups that had higher tendencies to contact a GP for minor illnesses than others. Interventions could be aimed specifically at older adults and people from BAME communities, although further research or review of existing research is probably needed to better understand why these sub-groups contact GPs. 
In conclusion, a range of issues explain tendency to contact GPs for minor illness amenable to selfcare. These include personal characteristics, type of symptom, and health literacy levels. Populationlevel interventions are likely to be needed to address these issues.

\section{Funding}

This project was funded by the National Institute for Health Research (NIHR) Health Services and Delivery Research (ref: 15/136/12). The views expressed are those of the authors and not necessarily those of the NHS, the NIHR, or the Department of Health and Social Care. The funder did not play a role in the review.

\section{Ethical approval}

Ethical approval was received from the NatCen Research Ethics Committee (ref: P12598).

\section{Provenance}

Freely submitted; externally peer reviewed.

\section{Acknowledgements}

The authors would like to thank the National Centre for Social Research, who undertook this survey as part of their British Social Attitudes survey.

\section{References}

1. Hobbs FDR, Bankhead C, Mukhtar T, et al. Clinical workload in UK primary care: a retrospective analysis of 100 million consultations in England, 2007-14. The Lancet 2016; 387(10035): 2323-2330. DOI: https://doi.org/10.1016/ S0140-6736(16)00620-6

2. Palmer B. Is the number of GPs falling across the UK? https://www.nuffieldtrust.org.uk/news-item/is-the-number-ofgps-falling-across-the-uk (accessed 25 Feb 2020).

3. NHS England. GP patient survey 2018; https://www.england.nhs.uk/statistics/2018/08/09/gp-patient-survey-2018/ (accessed 25 Feb 2020).

4. Fielding S, Porteous T, Ferguson J, et al. Estimating the burden of minor ailment consultations in general practices and emergency departments through retrospective review of routine data in North East Scotland. Fam Pract 2015; 32(2): 165-172. DOI: https://doi.org/10.1093/fampra/cmv003

5. Bell C. Does Peppa Pig encourage inappropriate use of primary care resources? BMJ 2017; 359: j5397. DOI: https://doi.org/10.1136/bmj.j5397

6. Pope C, McKenna G, Turnbull J, et al. Navigating and making sense of urgent and emergency care processes and provision. Health Expect 2019; 22(3): 435-443. DOI: https://doi.org/10.1111/hex.12866

7. Goode J, Greatbatch D, O'cathain A, et al. Risk and the responsible health consumer: the problematics of entitlement among callers to NHS direct. Crit Soc Policy 2004; 24(2): 210-232. DOI: https://doi.org/10.1177/ 0261018304041951

8. Hannay D. GPs and minor ailments. Br J Gen Pract 2010; 60(575): 451 DOI: https://doi.org/10.3399/ bjgp10X509649

9. Greenfield G, Ignatowicz A, Gnani S, et al. Staff perceptions on patient motives for attending GP-led urgent care centres in London: a qualitative study. BMJ Open 2016; 6(1): e007683. DOI: https://doi.org/10.1136/bmjopen2015-007683

10. McAteer A, Yi D, Watson V, et al. Exploring preferences for symptom management in primary care: a discrete choice experiment using a questionnaire survey. Br J Gen Pract 2015; 65(636): e478-e488. DOI: https://doi.org/10. 3399/bjgp15X685705

11. Porteous $\mathrm{T}$, Ryan M, Bond CM, et al. Preferences for self-care or professional advice for minor illness: a discrete choice experiment. Br J Gen Pract 2006; 56(533): 911-917.

12. Rennie L, Porteous T, Ryan M. Preferences for managing symptoms of differing severity: a discrete choice experiment. Value Health 2012; 15(8): 1069-1076. DOI: https://doi.org/10.1016/j.jval.2012.06.013

13. Phillips M, Albakri M, Cheesbrough S. Emergency care: what do attitudes tell us about demand for services and how it might be reduced? London: The National Centre for Social Research; 2019.

14. Curtice J, Clery E, Perry J, et al. British social attitudes: the 36th report. London: The National Centre for Social Research; 2019

15. O'Cathain A, Connell J, Long J, Coster J. 'Clinically unnecessary' use of emergency and urgent care: a realist review of patients' decision making. Health Expect 2020; 23(1): 19-40. DOI: https://doi.org/10.1111/hex.12995

16. National Statistics. English indices of deprivation 2015. London: Department for Communities and Local Government; 2015.

17. Hunter C, Chew-Graham C, Langer S, et al. A qualitative study of patient choices in using emergency health care for long-term conditions: the importance of candidacy and recursivity. Patient Educ Couns 2013; 93(2): 335-341. DOI: https://doi.org/10.1016/j.pec.2013.06.001 
18. Osborne RH, Batterham RW, Elsworth GR, et al. The grounded psychometric development and initial validation of the health literacy questionnaire (HLQ). BMC Public Health 2013; 13(1): 658. DOI: https://doi.org/10.1186/1471 2458-13-658

19. Leventhal $H$, Phillips LA, Burns E. The Common-Sense Model of self-regulation (CSM): a dynamic framework for understanding illness self-management. J Behav Med 2016; 39(6): 935-946. DOI: https://doi.org/10.1007/s10865016-9782-2

20. Andersen RM. Revisiting the behavioral model and access to medical care: does it matter? J Health Soc Behav 1995; 36(1): 1-10. DOI: https://doi.org/10.2307/2137284

21. Chatterjee S, Price B. Regression analysis by example. New York, NY: John Wiley and Sons; 1977.

22. Adamson J, Ben-Shlomo Y, Chaturvedi N, Donovan J. Exploring the impact of patient views on 'appropriate' use of services and help seeking: a mixed method study. Br J Gen Pract 2009; 59(564): e226-e233. DOI: https://doi.org/ 10.3399/bjgp09X453530

23. Chapron $A$, Brochard $M$, Rousseau $C$, et al. Parental reassurance concerning a feverish child: determinant factors in rural general practice. BMC Fam Pract 2018; 19(1): 7. DOI: https://doi.org/10.1186/s12875-017-0686-1

24. Kai J. What worries parents when their preschool children are acutely ill, and why: a qualitative study. BMJ 1996 313(7063): 983-986. DOI: https://doi.org/10.1136/bmj.313.7063.983

25. Zola IK. Culture and symptoms - an analysis of patients' presenting complaints. Am Sociol Rev 1966; 31(5): 615-630. DOI: https://doi.org/10.2307/2091854

26. Fisher RFR, Croxson CHD, Ashdown HF, Hobbs FDR. GP views on strategies to cope with increasing workload: a qualitative interview study. Br J Gen Pract 2017; 67(655): e148-e156. DOI: https://doi.org/10.3399/bjgp17X688861

27. Little $\mathrm{P}$, Somerville J, Williamson I, et al. Randomised controlled trial of self management leaflets and booklets for minor illness provided by post. BMJ 2001; 322(7296): 1214-1217. DOI: https://doi.org/10.1136/bmj.322.7296. 1214 